\title{
Necessity and Opportunity Entrepreneurship in Canada
}

\section{FLORENCE NEYMOTIN}

\author{
Carleton University and Nova Southeastern University. *
}

\begin{abstract}
The present analysis examines the initiation of necessity and opportunity entrepreneurship ventures in Canada from the late 1980s until more recent times, to determine how these activities relate with the business cycle. The definitions of necessity and opportunity entrepreneurship mirror those in Fairlie and Fossen (2018). Unlike previous results for other countries, I find that in Canada, both necessity and opportunity entrepreneurship appear to be procyclical, with new ventures increasing as unemployment declines. These results hold after various robustness tests, including gender stratification are applied. The possibility of using these forms of entrepreneurship as leading or lagged indicators of recessions is also considered.
\end{abstract}

Keywords: Opportunity Entrepreneurship; Necessity Entrepreneurship; Business Cycle; Canada

JEL Codes: J23, L26, P52

\section{Introduction}

Is entrepreneurship fundamentally counter- or procyclical? That is, do more people become entrepreneurs because they are "pushed" out of necessity - when they have little to no other employment options - or are they "pulled" to leave viable jobs to pursue better entrepreneurial ventures? (Calderon, Iacovone, and Juarez 2017; Caliendo and Kritikos 2009; Dawson and

\footnotetext{
* Fulbright Distinguished Chair in Entrepreneurship (2019-2020), Sprott School of Business, Carleton University. Associate Professor of Decision Sciences, Huizenga College of Business, Nova Southeastern University. Mailing Address: 3301 College Ave., Fort Lauderdale, FL, 33314, USA. Email: fneymotin@nova.edu

I would like to thank Statistics Canada for allowing me to access the Canadian 1986-2018 Labor Force Survey data through the Research Data Centre at the University of Ottawa and my contracted (unpaid) work through Statistics Canada. All required clearances were completed prior to data access. Data can be accessed via application and acceptance by qualified research projects to Statistics Canada. I would like to thank David Card, Frances Woolley, Louis-Phillippe Morin, Dana Brown, and Anna Dammert for useful comments and suggestions. All mistakes are my own. I have no financial conflicts to disclose.

(C) 2021 Florence Neymotin . Licensed under the Creative Commons Attribution - Noncommercial 4.0 Licence (http://creativecommons.org/licenses/by-nc/4.0/. Available at http: //rofea.org.
} 
Henley 2012; Giacomin et al. 2011; Hughes 2003; Moore and Mueller 2002). This question of necessity versus opportunity entrepreneurship has many implications for public policy, both regarding the promotion of small business formation, as well as its utility as a gauge of overall economic health. ${ }^{1}$

Opportunity entrepreneurs may be leaving bad jobs because there just aren't enough good positions in the market with characteristics such as sufficient pay, benefits, and self-realization, to go around (Acemoglou 2001; Farber 1999; Green et al. 2016; Piasna 2017; Riddell 2009). Since the business cycle is often, although not always, thought to relate with unemployment rates (Giacomin et al. 2011; Koellinger and Thurik 2012; Lin et al. 2000; Moore and Mueller 2002; Riddell 2009; Schuetze 2000), authors have examined the pro-cyclical versus countercyclical nature of various forms of entrepreneurship (Becker 1984; Congregado, Golpe, and Parker 2012; Fairlie and Fossen 2018; Parker et al. 2012). While related questions have been considered, the fundamental issues of necessity vs. opportunity entrepreneurship and their relationship with business cycles have not been studied in Canada using recent data. Specifically, a number of authors have examined patterns of recent "immigrant" entrepreneurship in Canada (Green et al. 2016; Ostrovsky et al. 2019; Ostrovsky and Picot 2018); others have explored overall entrepreneurship in countries other than Canada (Fairlie and Fossen 2018; Ensign and Robinson 2011); finally, some have indeed examined entrepreneurship in Canada and how it relates with job choice, but only for limited samples or in years prior to the 1990s (Bouderbat, Lemieux, and Riddell 2010; Hughes 2003; Lin et al. 2000; Schuetze 2000);

The present analysis is the first to examine whether necessity and opportunity entrepreneurship in Canada behave in a procyclical or countercyclical fashion during the period of 1986 to 2018. This contribution for Canada is especially important given its unique situation with respect to rising income inequality in the 1990s, changes in returns to skills, and changes in union impact over time (Boudarbat et al. 2010; Card, Lemieux, and Riddell 2003; Green and Sand 2013; Riddell 2009). It is also important given differences in the regulatory structure in Canada, particularly in how easy it is for individuals to receive unemployment benefits (Card and Riddell 1995; Riddell 2009). The implications of the results gathered here will also help guide the discussion of whether various forms of entrepreneurship can be seen as leading or lagging indicators of recessions.

To this end, the present work employs a unique new method that builds on the structure outlined in Fairlie and Fossen (2018) - in which German and U.S. entrepreneurship were the focus - to determine that Canadian entrepreneurship rates appear to behave in a procyclical fashion. Regardless of whether they are driven by necessity or opportunity, or incorporation,

\footnotetext{
${ }^{1}$ Notice that this distinction does not depend on profit maximization or cost minimization per se
} (Kumbhakar and Tsionas, 2016). 


\section{NEYMOTIN Necessity and Opportunity Entrepreneurship}

entrepreneurs begin their ventures in Canada at higher rates when the economy is relatively good. It does not appear, however, that the magnitude of the effects are particularly large. I interpret this result in terms of the particular regulatory, tax, and labor market structure in Canada. The results are particularly important given the present-day global situation and possibilities for future new business creation. For instance, government payments to either businesses or individuals can be interpreted keeping in mind any discovered relationships between the types of entrepreneurship and economic business cycle. Clearly, however, these relationships will be multifaceted.

\section{Materials and Methods}

\subsection{Data}

Data were drawn from the restricted-access 1986-2018 Canadian Labor Force Survey (LFS), accessed through a Statistics Canada Research Data Center (RDC) at the University of Ottawa (COOL-RDC). ${ }^{2}$ The Labor Force Survey was chosen because of the structure of its sampling methodology, with each sampled individual remaining in the survey for a period of six months at a time. Equal portions of individuals were cycled in and out each month, with a somewhat similar structure to the Current Population Survey in the United States-albeit with no resampling after individuals were rotated out of the sample. This allowed for individuals to be followed to determine how they transitioned into or out of entrepreneurship each month. My focus was on the 20 to 64 -year-old population. Individuals were identified uniquely through their line number and household ID.

Specifically, I considered an individual to be a new entrepreneur if they answered the question on their main type of employment as being "self-employed"-whether incorporated or not, and whether their venture had other employees or not—and had not been self-employed in the previous month when they were in the sample. Creating these two-month pairs for individuals meant that each person in the sample could have up to five opportunities to be a "new" entrepreneur. They were also allowed to transition in and out of entrepreneurship, so that the individual could be both a new entrepreneur in, for example, month two and month six of their time in the survey.

I defined necessity entrepreneurs within this group of new entrepreneurs as those individuals who answered their previous labor force status question - the month before they said they were self-employed — as "out of the labor force but able to work," the standard U3 definition of

\footnotetext{
2 All summary statistics and regression data were disclosed for unweighted samples of at least 30 observations or more in each cell or correlation as per research guidelines at Statistics Canada. The unweighted data were chosen since they are similar to the data available in other countries. It should be noted, however, that the lack of weighting may make it less representative, given the typical methodology of weighting suggested by Statistics Canada.
} 
unemployment (temporary layoff, job searchers, future start date). In contrast, opportunity entrepreneurs were those individuals whose status was 'in the labor force' and they had been "employed" for either a public or private institution in the month preceding their selfemployment. This methodology is in keeping with Fairlie and Fossen (2018). ${ }^{3}$

To assess the business cycle information, the unemployment rate was constructed at the national level employing the LFS with unemployrate $=($ unemployed $) /($ employed + unemployed $)$. Information on the percentage change in quarterly Gross Domestic Product (GDP), which is the quarterly GDP growth rate, was drawn from the OECD survey of nations. ${ }^{4}$

\subsection{Methodology}

The main goal of the empirical section was to determine how various individual characteristics and a proxy for the business cycle - the unemployment rate-predict rates of new entrepreneurship. To this end, I employed both a linearized regression structure as well as Probits and their associated marginal regression effects. The general structure was, for individual $i$ in time $t$ :

Entrepreneur $_{i, t}=f\left(\right.$ Unemployment $_{t}$, Province $_{i, t}$, Sex $_{i,}$, Age $_{i, t}$, Educ $_{\cdot i, t}$, MarStat $\left._{i, t}\right)$

where Entrepreneur was a binary outcome for, alternatively, whether an individual was a new entrepreneur, a new necessity entrepreneur, or a new opportunity entrepreneur; Province included a series of binary variables for the ten Canadian provincial areas; Sex was binary; MarStat split individuals into either being together (married or cohabiting), apart (widowed, divorced, separated), or single and never married; Educ (education) was broken down based on the structure in the LFS with categories including up to ten years of education, 11-13 years of education, some postsecondary education or a postsecondary degree, and, finally, education past the postsecondary level; Age and its square were included in a continuous fashion. I also included a quadratic in the time period to account for changes in entrepreneurial patterns over this extended period of time, and clustered standard errors at the person-level in accordance with the nature of the analysis. ${ }^{5}$

3 The exact wording in Fairlie and Fossin (2018) is: “...individuals who are initially unemployed before starting businesses are defined as "necessity" entrepreneurs, and individuals who are wage/salary workers, enrolled in school or college, or are not actively seeking a job are defined as "opportunity" entrepreneurs". The Fairlie and Fossin definition groups individuals who are enrolled in school and those who are not actively seeking work (but able to work) as opportunity, rather than necessity, entrepreneurs. For this reason, a robustness check alters where these individuals are placed - making them opportunity rather than necessity entrepreneurs, and finds that these individuals are not the determining factor in the patterns observed.

${ }^{4}$ https://data.oecd.org/gdp/quarterly-gdp.htm

${ }^{5} \mathrm{~A}$ robustness check (results not shown due to disclosure restrictions) employing clustering at higher levels of aggregation yielded similar patterns of results with, in certain cases, slightly less significant 
There were also several variables employed for the summary statistics or figures. In particular, Industry employed the first two digits of the North American Industry Classification System (NAICS) 2012 code $^{6}$; Incorporation determined how many of the new self-employed entrepreneurs were incorporated; and Employed examined how many of the new entrepreneurs had any employees.

\section{Results}

\subsection{Summary Statistics}

Table 1 displays the mean characteristics of new entrepreneurs in the sample. In keeping with prior expectations, opportunity entrepreneurs, as opposed to necessity entrepreneurs, were more likely to have incorporation ( $38.7 \%$ vs. $18.6 \%$ ) or employees ( $32.6 \%$ vs. $15.2 \%)$. The increased rate of opportunity versus necessity entrepreneurs is also in keeping with the literature (Robichaud et al. 2017) There is also a somewhat different distribution of industries, with the top four industries for necessity entrepreneurs being Professional/Business, Agriculture, Other Service, and Construction. In contrast, opportunity entrepreneurs are mostly concentrated in the same areas, with Wholesale representing a larger percentage compared with Agriculture for the opportunity entrepreneurs. This is also as to be expected. Neither type of entrepreneur is particularly concentrated in areas such as Information, Education/Health, Financial, or Manufacturing. This may be different than the patterns of other countries, where these areas could support more entrepreneurial work.

Figures 1-8 examine patterns of entrepreneurship over time as related with both the percentage change in national GDP and national unemployment rates. ${ }^{7}$ The numbers of total new entrepreneurs, new necessity entrepreneurs, new opportunity entrepreneurs, and new incorporated entrepreneurs are examined.

Figures 1-4 demonstrate that, as unemployment has "generally" been falling, all of opportunity, incorporated, and total new entrepreneurship have been rising, with a sharp increase around 2004-2005. Since entrepreneurship was provided in raw amounts, seasonal trends are also

coefficients. Clustering at the individual level can be motivated due to variation in a "fixed effects" sense, however, the robustness analyses employed a more province-time approach in keeping with the idea that clusters should be larger to create the most conservative standard errors given the largest level of aggregation of variables in the data (unemployment).

${ }^{6}$ Agriculture: 1100s; Construction: 2300s; Manufacturing: 3100s-3300s; Wholesale/Retail/Trade: 4100s, 4400s-4500s; Transport: 4800s-4900s; Information: 5100s; Financial Activity: 5200s; Professional/Business/Public Administration: 5400s-5600s, 9100s; Education/Health: 6100s-6200s; Leisure/Hospitality: 7100s-7200s; Other Service: 8100 s.

${ }^{7}$ While GDP measures were used in the figures, OECD data were not separately imported into the RDC, so those regressions use unemployment only. 
apparent in the data. The pattern also appears more generally with respect to necessity entrepreneurs, with a similar rise, but less of a pronounced jump over time.

At this point, it would be reasonable to conclude that entrepreneurship moves pro-cyclically. It would also appear that, at least for 2005, opportunity (but not necessity) entrepreneurship may appear to be a leading indicator for recessions. However, since this same jump is not present prior to the recession of the 1990s in Canada, the use of new entrepreneurship as a leading indicator may not be as helpful. But, figures 5-8 do not show this same picture, as GDP growth rates typically vary over time. As an alternative possibility, the Conservative party took control of the government in January of 2006, leading to a very pro-business environment. This change in party and policy was generally anticipated after the political scandal in February of 2004 related with the previous Prime Minister that ultimately led to a vote of no confidence. This historical and policy-related explanation is in keeping with the data. Clearly then, a more in-depth regression analysis is necessary.

Table 1: Mean Traits of New Entrepreneurs

\begin{tabular}{|l||c|c|}
\hline & $\begin{array}{c}\text { New Necessity } \\
\text { Entrepreneur }\end{array}$ & $\begin{array}{c}\text { New Opportunity } \\
\text { Entrepreneur }\end{array}$ \\
\hline \hline Incorporated & $18.60 \%$ & $38.70 \%$ \\
\hline Employer & $15.20 \%$ & $32.60 \%$ \\
\hline Agriculture & $15.40 \%$ & $9.90 \%$ \\
\hline Construction & $11.00 \%$ & $14.90 \%$ \\
\hline Manufacturing & $2.30 \%$ & $3.40 \%$ \\
\hline Wholesale & $10.90 \%$ & $11.30 \%$ \\
\hline Transport/Utility & $3.80 \%$ & $6.80 \%$ \\
\hline Information & $0.70 \%$ & $0.80 \%$ \\
\hline Financial & $1.40 \%$ & $2.40 \%$ \\
\hline Prof./Bus. & $18.40 \%$ & $17.30 \%$ \\
\hline Educ/Health & $2.60 \%$ & $2.20 \%$ \\
\hline Leisure/Hosp & $7.50 \%$ & $7.70 \%$ \\
\hline Other Service & $12.40 \%$ & $9.30 \%$ \\
\hline No Industry Listed & $13.60 \%$ & $14.20 \%$ \\
\hline \hline Sample Size & 59124 & 156279 \\
\hline
\end{tabular}

Note: The sample consists of individuals ages 20-64.

Source: Labor Force Survey of Canada (1986-2018). 
Figure 1 : \# New Entrepreneurs and Unemployment Rate

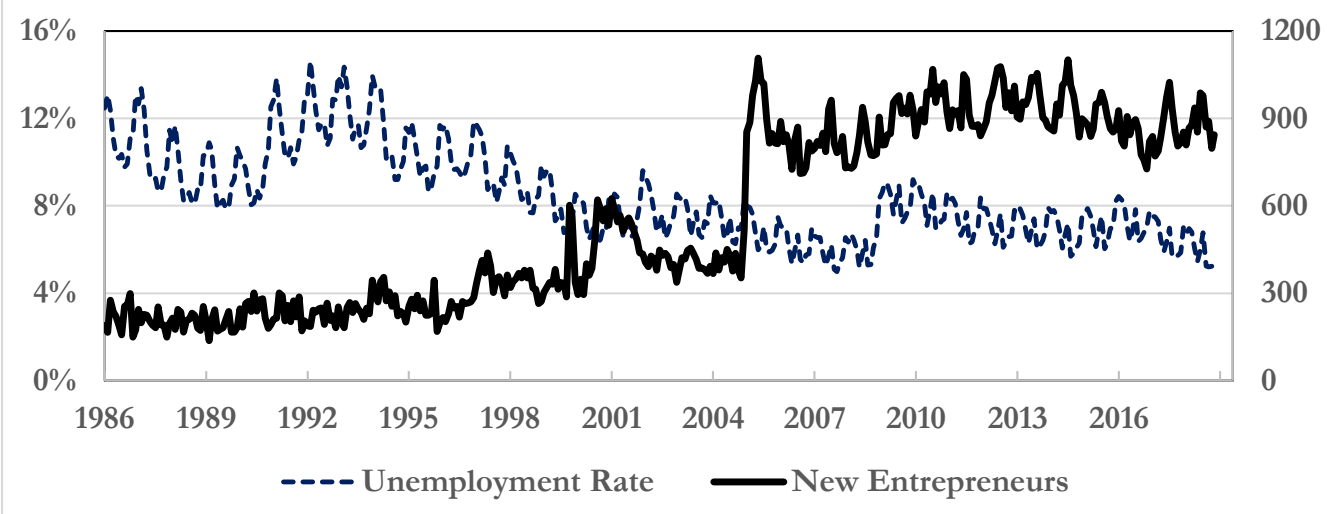

Figure 2:\#New Necessity Entrepreneurs \&Unemployment Rate

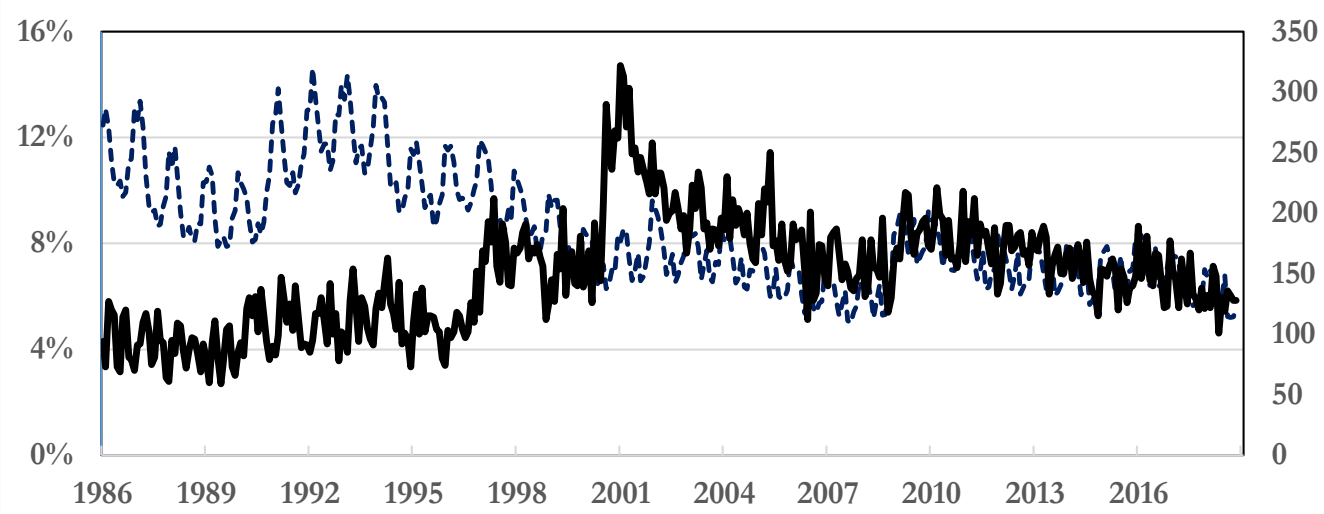

---- Unemployment Rate — New Necessity Entrepreneurs

Figure3:\#New Opportunity Entrereneurs \&Unemployment Rate

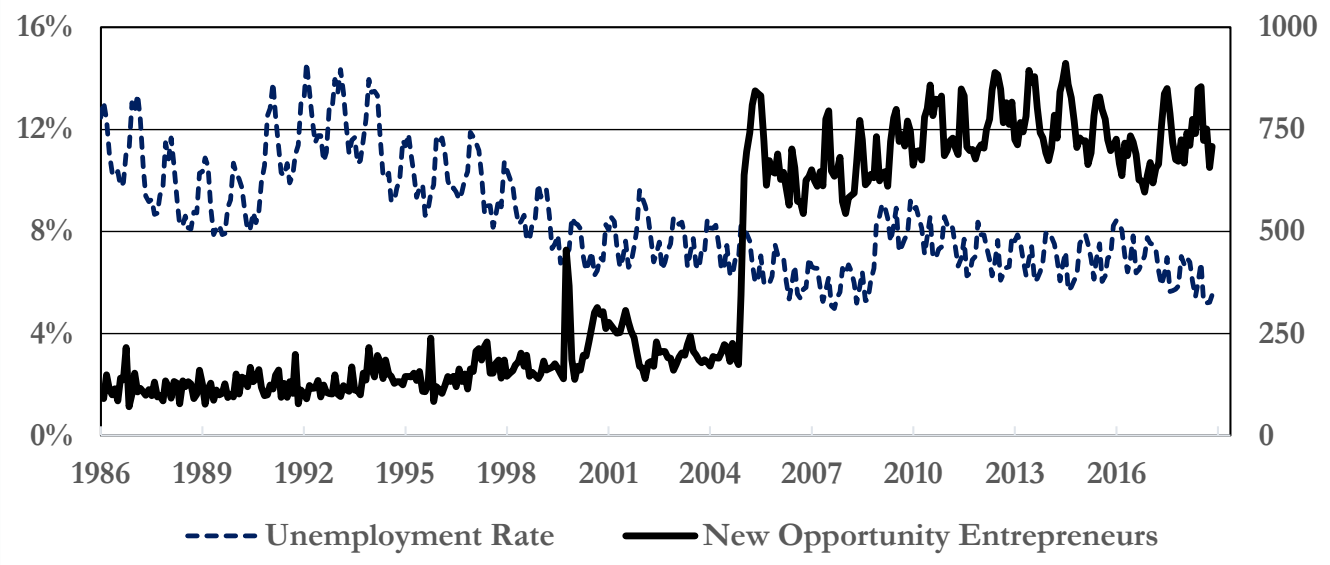


Figure 4:\# New Incorp Entrepreneurs and Unemployment Rate

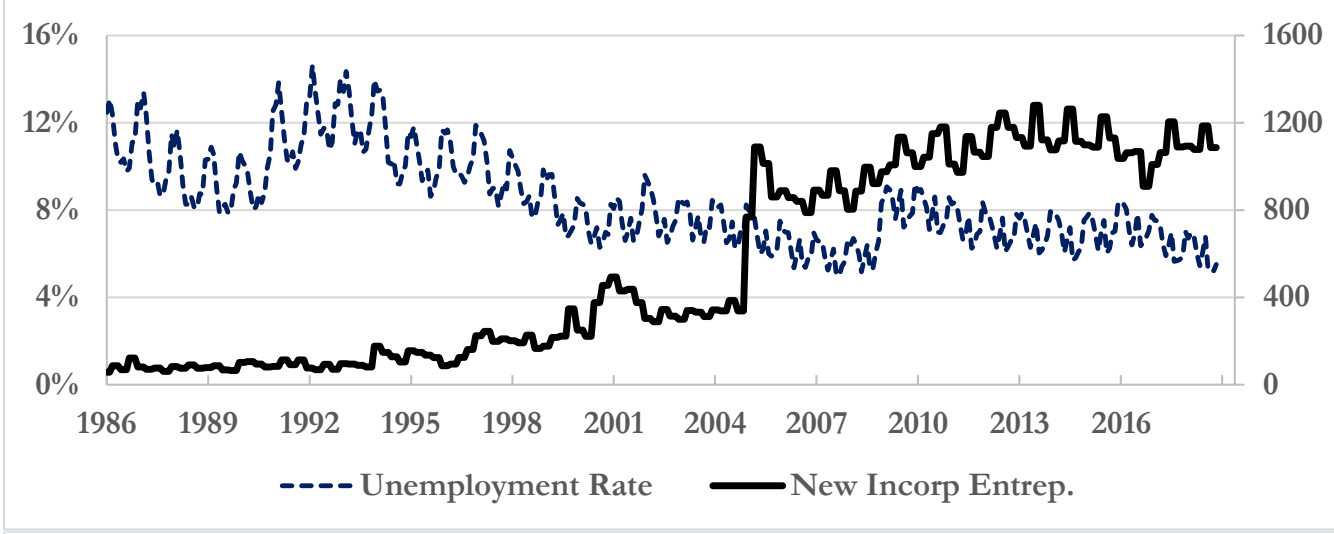

Figure 5: \# New Entrepreneurs \& GDP

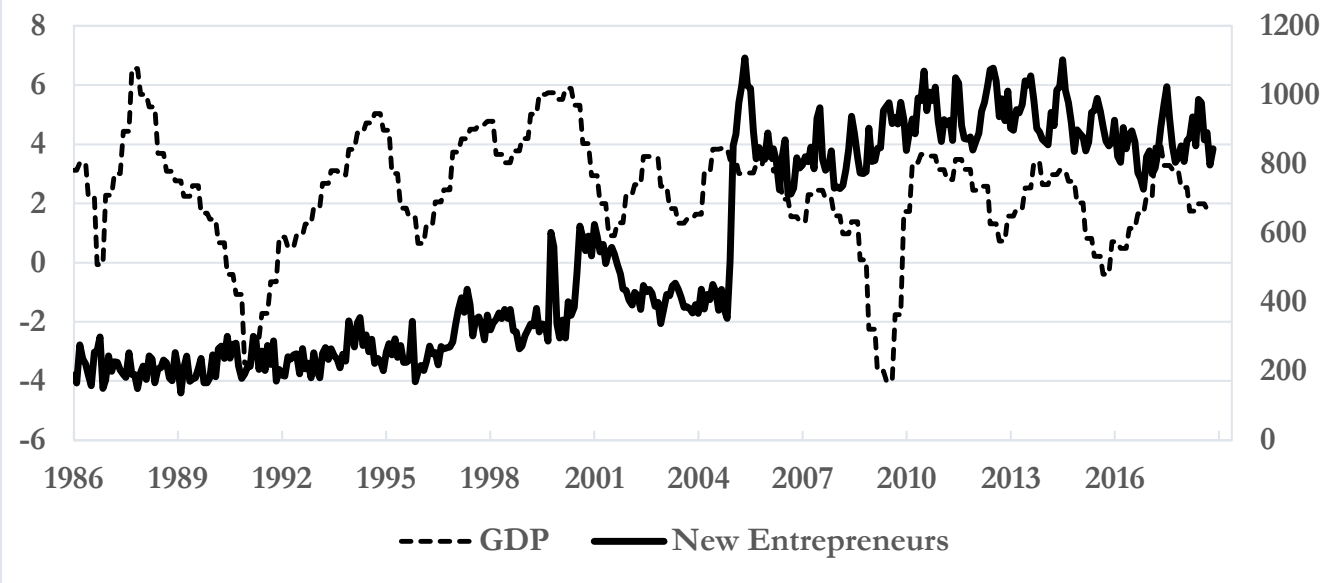

Figure 6: \# New Necessity Entrepreneurs \& GDP

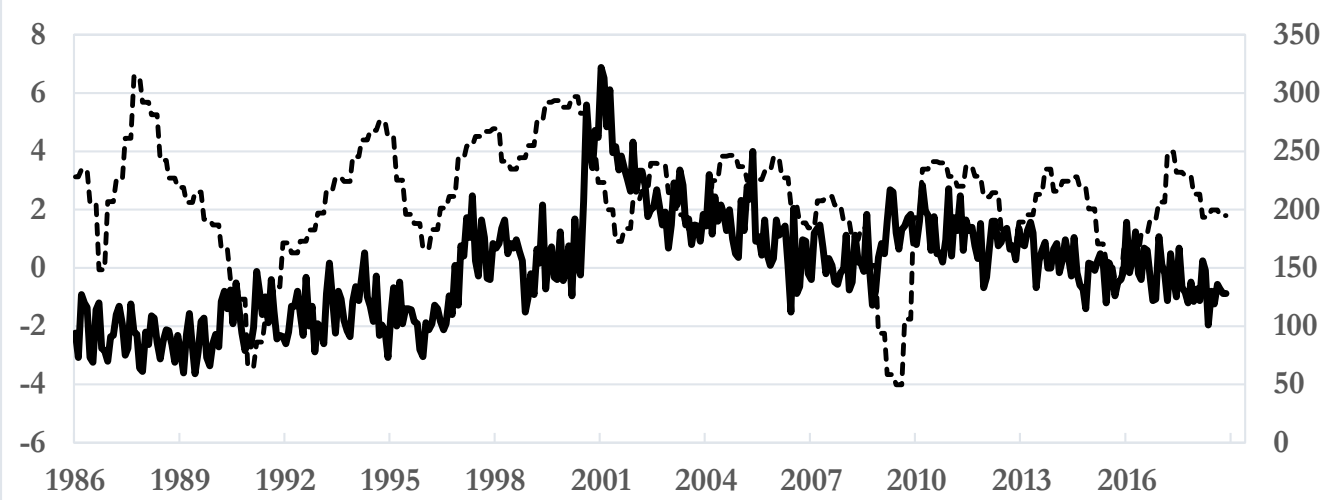

--- GDP $\longrightarrow$ New Necessity Entrepreneurs 
Figure 7: \# New Opportunity Entrepreneurs \& GDP

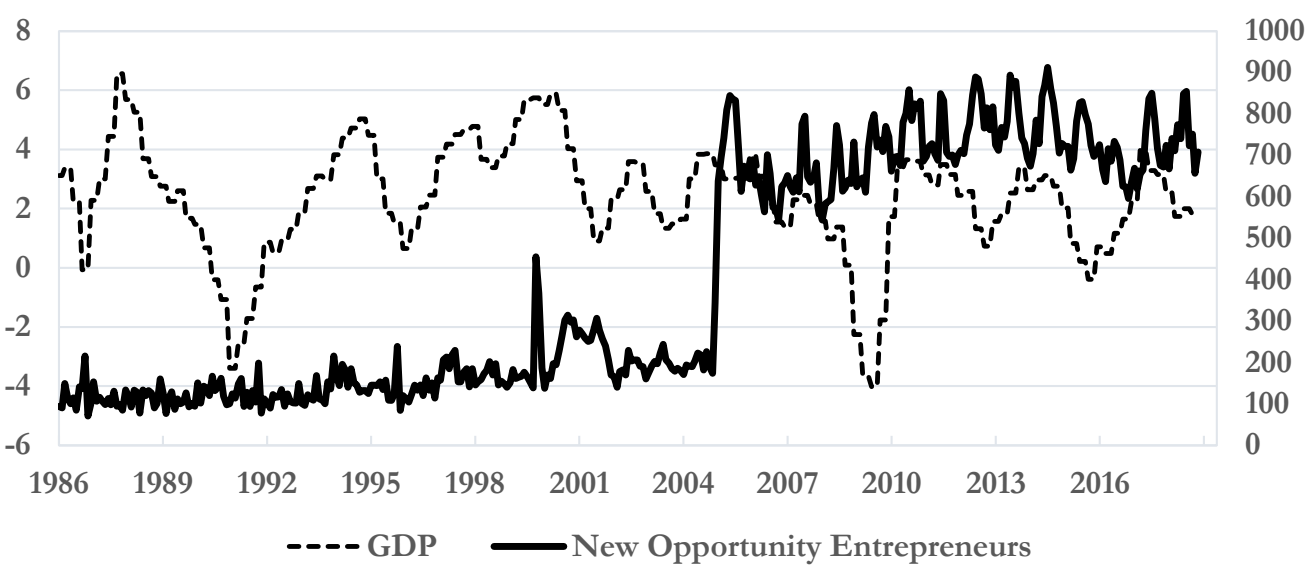

Figure 8: New Incorp. Entrepreneurs and GDP

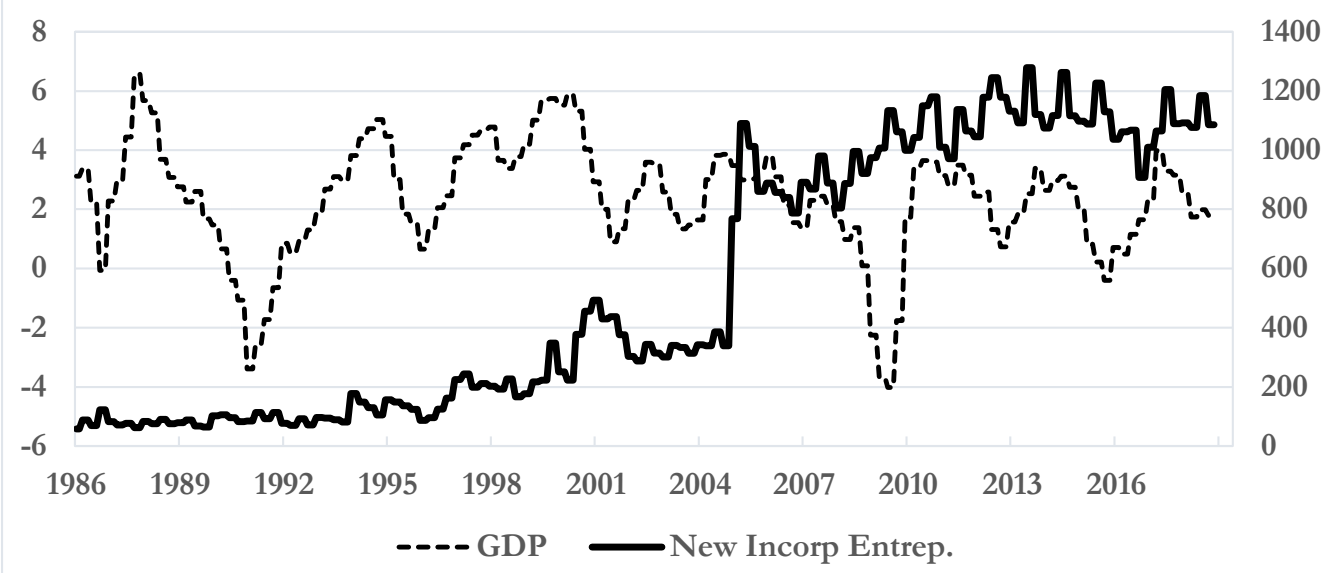




\subsection{Regressions}

Table 2 displays the results of linearized regressions and marginal Probits, with the left-handside outcome variable defined as a binary measure of new total, necessity, or opportunity entrepreneurship, respectively. Demographic controls as well as time and regional controls are also employed. As evidenced from this table, and interesting considering the previous literature, the unemployment rate is negatively related to all forms of entrepreneurship. While this relationship is small in magnitude and less significant for necessity entrepreneurship, no types of entrepreneurship are seen to increase during economic downturns. This stands in contrast with previous studies, such as Fairlie and Fossen (2018), that hypothesized that necessity and opportunity entrepreneurship have opposite-signed relationships with the unemployment rate, with necessity (opportunity) entrepreneurship increasing (decreasing) in downturns. It is still premature to attempt to infer causal impacts from these results, and the possibility of entrepreneurship as a lagging or leading indicator of unemployment is not explored here, but left for future work to detail.

The Canadian result can be interpreted in light of the particular institutions and climate for fostering entrepreneurship in Canada. ${ }^{8}$ Individual entrepreneurs may be subject to higher tax rates than in Germany or in the United States, particularly as they grow in income, and Canadians also have lower levels of disposable income and liquidity (Tal, 2019 ). ${ }^{9}$ More simply put, while an economic downturn typically makes buying capital and investing in a new business cheaper, individuals are often living with too many liquidity constraints to take advantage of these additional opportunities. It is also the case that employment arrangements, often being longer-term than those in the United States, for example, would make beginning a new business a riskier endeavor if it means leaving a stable job. This could explain why Canada does not exhibit the same patterns of effects as one would expect from necessity and opportunity entrepreneurs in a downswing or upswing in the economy.

\footnotetext{
8 While Deans and Kroeger (2004) note that only 30\% of a company's growth is a function of outside, rather than inside factors, $30 \%$ is a non-negligible portion. In the current context, differences between countries and/or over time can lead to substantial differences in individuals' interest in starting a business. One example explored in some detail here is the possibility that higher liquidity constraints in Canada versus other countries led to differences in rates of entrepreneurship. Another possibility to consider is that differing rates of immigration can lead to variations in rates of entrepreneurship. Specifically, since immigrants, and other "outsiders" - in the language of Ensign and Robinson (2016)—enjoy a unique incentive and ability to engage in entrepreneurship, changes in rates of immigration could lead to increases in certain forms of entrepreneurship.

9 As an illustration, new entrepreneurship counts of 400-1500 per month compare very unfavorably to those in Fairlie and Fossen (2018) for the United States and Germany. In that analysis, the United States had 50,000-100,000 new monthly entrepreneurs during many points during this time period. While having ten times more individuals in the United States (37.7 million in Canada versus 332.6 million in the U.S. based on latest estimates www.mylifeelsewhere.com), the United States may have closer to one hundred times as many entrepreneurs.
} 
NEYMOTIN Necessity and Opportunity Entrepreneurship

Table 2: Regressions for Probability of Entrepreneurship by Type

\begin{tabular}{|c|c|c|c|c|}
\hline \multicolumn{5}{|c|}{ New Entrepreneurs } \\
\hline & OLS & dProbit & OLS & dProbit \\
\hline \multirow[t]{2}{*}{ Natl. Unemployment Rate } & -0.155 & -0.171 & -0.031 & -0.034 \\
\hline & {$[-210.66]^{* *}$} & {$[-190.49]^{* *}$} & {$[-30.15]^{* *}$} & {$[-29.18]^{* *}$} \\
\hline Demographic Controls & & & $\mathrm{x}$ & $\mathrm{x}$ \\
\hline Regional Controls & & & $\mathrm{x}$ & $\mathrm{x}$ \\
\hline Quadratic Time Trend & & & $\mathrm{x}$ & $\mathrm{x}$ \\
\hline $\mathrm{N}$ & $27,537,035$ & $27,537,035$ & $25,937,065$ & $25,937,065$ \\
\hline \multicolumn{5}{|c|}{ Necessity Entrepreneurs } \\
\hline & $O L S$ & dProbit & OLS & dProbit \\
\hline \multirow[t]{2}{*}{ Natl. Unemployment Rate } & -0.018 & -0.02 & -0.008 & -0.007 \\
\hline & {$[-48.2]^{* *}$} & {$[-45.74]^{* *}$} & {$[-14.66]^{* *}$} & {$[-11.45]^{* *}$} \\
\hline Demographic Controls & & & $\mathrm{x}$ & $\mathrm{x}$ \\
\hline Regional Controls & & & $\mathrm{x}$ & $\mathrm{x}$ \\
\hline Quadratic Time Trend & & & $\mathrm{x}$ & $\mathrm{x}$ \\
\hline $\mathrm{N}$ & $27,377,354$ & $27,377,354$ & $25,795,045$ & $25,795,045$ \\
\hline \multicolumn{5}{|c|}{ Opportunity Entrepreneurs } \\
\hline & OLS & dProbit & OLS & dProbit \\
\hline \multirow[t]{2}{*}{ Natl. Unemployment Rate } & -0.135 & -0.149 & -0.021 & -0.026 \\
\hline & {$[-216.18]^{* *}$} & {$[-193.15]^{* *}$} & {$[-25.62]^{* *}$} & {$[-28.48]^{* *}$} \\
\hline Demographic Controls & & & $\mathrm{x}$ & $\mathrm{x}$ \\
\hline Regional Controls & & & $\mathrm{x}$ & $\mathrm{x}$ \\
\hline Quadratic Time Trend & & & $\mathrm{x}$ & $\mathrm{x}$ \\
\hline $\mathrm{N}$ & $27,474,509$ & $27,474,509$ & $25,878,022$ & $25,878,022$ \\
\hline
\end{tabular}

Note: The sample consists of individuals ages 20-64 who do not own a business in the initial month in a two month panel. Demographic controls include gender, age, age squared, education levels, and marital status dummies. Regional controls include dummies for provinces. Standard errors are clustered at the individual-level. Coefficients are shown with associated t-statistics, ${ }^{* *}$ indicates significant at the $1 \%$ level.

Source: Labor Force Survey of Canada (1986-2018)

Several robustness checks and alternatives are also presented in Appendix Table 1. First, to be in exact accordance with Fairlie and Fossen (2018), I altered the measures of entrepreneurs so that opportunity, rather than necessity, entrepreneurs included individuals who were out of the 
labor force but able to work. I also included only those observations for which an individual had been working for at least fifteen hours per week at their main stated job-since this would indicate that they were truly entrepreneurs as their main form of employment. Second, local and national unemployment rates were used in separate regressions. Third, incorporation was employed as an alternative outcome for type of entrepreneurship - left out of the main results due to concerns regarding possible endogeneity in the choice to incorporate ${ }^{10}$. Finally, regressions were split by gender, while simultaneously employing the alternate measure of necessity entrepreneurship, allowing comparisons with local unemployment rates, and presenting incorporation as an outcome.

It is clear from Appendix Table 1 that in all the considered alternatives, similar patterns of results were obtained as seen in the baseline. The local unemployment rate appears to be somewhat less important in affecting entrepreneurship compared with the national rate, and patterns for incorporated entrepreneurs look similar to those for opportunity or new entrepreneurs more generally. While coefficients for necessity entrepreneurship do appear to be less negative, significance levels were also dramatically decreased and there were no instances where unemployment moves positively and significantly with necessity entrepreneurship. ${ }^{11}$ I take this as further evidence that, even in robustness checks with varying definitions for entrepreneurship, new necessity entrepreneurship is not countercyclical in nature. It does appear, that necessity entrepreneurship probably has, if anything, a very small procyclical relationship with the business cycle.

Appendix Table 2 shows the results of the gender-specific regressions. It should be noted that $\mathrm{t}$-tests for differences in the betas of the unemployment coefficients were almost always significant at the $5 \%$ or $1 \%$ levels. This includes all but two of (each of) the gender differences, the national-local differences, and the difference between the controlled and uncontrolled versions of the regressions. All the regressions in which the differences did not reach statistical significance were in the necessity entrepreneurship section.

\footnotetext{
10 The same construction of entrepreneurs as in Fairlie and Fossen (2018) was not exactly used in the main regression since (a) it was unclear that this was the only way to interpret how individuals transitioned into and out of the labor force. This is particularly true for Canada where it is much simpler to be considered "unemployed and actively seeking work," and (b) there were significant issues in disclosing summary statistics associated with the full Fairlie and Fossen (2018) methodology, due to smaller samples in the necessity entrepreneur groups. As demonstrated, the slight variation in constructing entrepreneurs that was employed here did not substantively impact the main results relative to the alternative construction.

${ }_{11}$ An argument can be made for including local unemployment, rather than national unemployment, in the baseline analysis since individuals may respond more to changes at the local level. This was not done for several reasons: First, this would be less analogous to the Fairlie and Fossen (2018) methodology. Second, it is not a given that local patterns are more important than national trends in unemployment in guiding entrepreneurship choices. And third, this analysis truly aims to test whether necessity entrepreneurship has a "positive" relationship with unemployment, and that purpose is achieved regardless of which level of unemployment is used in the baseline or in the robustness analysis.
} 


\section{NEYMOTIN Necessity and Opportunity Entrepreneurship}

In keeping with previous results, Appendix Table 2 demonstrates a generally procyclical pattern for all forms of entrepreneurship. While the effects for women were almost always smaller in magnitude, the overall difference in size was still quite small, and the magnitudes typically went in the same direction. Local rates still appeared to have less impact than national rates, and the controls mattered in dampening the effects of unemployment. The only result that was not entirely in keeping with the patterns listed here is that, for women, but not men, local unemployment had a very slightly positive and statistically significant (countercyclical) relationship with necessity entrepreneurship.

This finding is the only indication in accord with the work of Fairlie and Fossen (2018) for Germany and the United States with regard to necessity entrepreneurs. The effect is so small in magnitude, however, (0.0002123), and the significance at the $10 \%$ level, so that the overall conclusion is that there is indeed no strong evidence in favor of the countercyclical nature of necessity entrepreneurship.

\section{Discussion}

The present analysis finds that both necessity and opportunity entrepreneurship in Canada move in a procyclical fashion, as proxied by the local or national unemployment rate. This result remains after robustness checks of varying forms, including the stratification of regressions by gender, and it stands in contrast with previous authors who have found that necessity entrepreneurship is countercyclical. This work is the first to detail the exact pattern of entrepreneurial trends in Canada over this 30+ year current time-period, and the first to test how Canadians choose to start businesses with respect to the business cycle. These results further highlight the need to exercise caution in extrapolating effects for Canada from its nearest neighbor, the United States.

In understanding these differences, I stress the importance of liquidity constraints in Canada as limiting the ability of entrepreneurship to react to cheaper business inputs. I would also highlight the need to focus on the stability of employer-employee relationships. If relationships tend to be longer or more secure in Canada than in the reference economies, then the choice to become an entrepreneur represents a riskier decision and is less likely to be undertaken. These possibilities are presented as suggestions for future research. ${ }^{12}$

\footnotetext{
${ }^{12}$ If for instance, a non-self-employed Canadian correctly believes that he is highly unlikely to lose his job, choosing to trade a relatively secure employment position for an inherently riskier entrepreneurial role would only be justified under large expected benefits. As a few possibilities, the reason for the increased safety in Canadian employment verus in other countries may relate to differing cultural norms making it harder to fire an individual from a company, it could relate to higher average training costs in Canada, or it may relate in a formal manner to the Canadian legal-employment-relationship-wherein the process of firing and rehiring employees could be more difficult, precluding most firms from doing so unless they experience extreme issues with employees.
} 
These correlations do not imply a causal direction. There is some evidence from the charts that opportunity forms of entrepreneurship could be a leading indicator of entrepreneurship. Since this requires a different type of empirical analysis, the question is left for future work. As seen in the present analysis, the two do not occur in a countercyclical fashion, and the very strong statistical significance of coefficients generally does imply that new entrepreneurship runs in tandem with upswings in the business cycle. Finally, if spurring entrepreneurship is a desired outcome of public policy, decision makers should be mindful of the possible influence of the overall business cycle. In particular, the notion that increased small business formation will naturally "grow" a sputtering economy out of a malaise should be tempered with this result that risk-aversion may suppress these ventures during downturns.

\section{Appendix}

Appendix Table 1: Linearized Regressions Predicting New Entrepreneurs

\begin{tabular}{|c|c|c|c|c|c|c|c|c|}
\hline & \multicolumn{4}{|c|}{ Incorporated Entrepreneurs } & \multicolumn{4}{|c|}{ New Entrepreneurs } \\
\hline \multirow{2}{*}{ Unemployment Rate } & -0.061 & -0.022 & -0.007 & -0.002 & -0.144 & -0.054 & -0.028 & -0.014 \\
\hline & {$[-171.7] * *$} & {$[-131.82]^{* *}$} & {$[-14.57]^{* *}$} & {$[-6.49]^{* *}$} & {$[-210.65]^{* *}$} & {$[-165.22]^{* *}$} & {$[-30.2]^{* *}$} & {$[-21.28]^{* *}$} \\
\hline Local Unemployment & & $\mathrm{x}$ & & $\mathrm{x}$ & & $\mathrm{X}$ & & $\mathrm{x}$ \\
\hline Demographic Controls & & & $\mathrm{x}$ & $\mathrm{x}$ & & & $\mathrm{X}$ & $\mathrm{x}$ \\
\hline Regional Controls & & & $\mathrm{x}$ & $\mathrm{x}$ & & & $\mathrm{X}$ & $\mathrm{x}$ \\
\hline Quadratic Time Trend & & & $\mathrm{x}$ & $\mathrm{x}$ & & & $\mathrm{X}$ & $\mathrm{x}$ \\
\hline \multirow[t]{2}{*}{$\mathrm{N}$} & 31015396 & 31015396 & 31015396 & 31015396 & 27754844 & 27754844 & 27754844 & 27754844 \\
\hline & \multicolumn{4}{|c|}{ Necessity Entrepreneurs } & \multicolumn{4}{|c|}{ Opportunity Entrepreneurs } \\
\hline \multirow{2}{*}{ Unemployment Rate } & -0.002 & 0 & 0 & 0 & -0.14 & -0.054 & -0.027 & -0.013 \\
\hline & {$[-8.65]^{* *}$} & [1.61] & {$[-1.29]$} & {$[-0.57]$} & {$[-215.77]^{* *}$} & {$[-173.86]^{* *}$} & {$[-30.43]^{* *}$} & {$[-21.49]^{* *}$} \\
\hline Local Unemployment & & $\mathrm{x}$ & & $\mathrm{x}$ & & $\mathrm{X}$ & & $\mathrm{x}$ \\
\hline Demographic Controls & & & $\mathrm{x}$ & $\mathrm{x}$ & & & $\mathrm{X}$ & $\mathrm{x}$ \\
\hline Regional Controls & & & $\mathrm{x}$ & $\mathrm{x}$ & & & $\mathrm{X}$ & $\mathrm{x}$ \\
\hline Quadratic Time Trend & & & $\mathrm{x}$ & $\mathrm{x}$ & & & $\mathrm{X}$ & $x$ \\
\hline $\mathrm{N}$ & 27576971 & 27576971 & 27576971 & 27576971 & 27736751 & 27736751 & 27736751 & 27736751 \\
\hline
\end{tabular}

Note: The sample consists of individuals ages 20-64 who do not own a business in the initial month in a two month panel. Demographic controls include gender, age, age squared, education levels, and marital status dummies. Regional controls include dummies for provinces. Standard errors are clustered at the individual-level. Coefficients are shown with associated t-statistics, $* *$ indicates significant at the $1 \%$ level.

Source: Labor Force Survey of Canada (1986-2018) 
NEYMOTIN Necessity and Opportunity Entrepreneurship

Appendix Table 2: Linearized Regressions of the Unemployment Rate on Measures of Entrepreneurship Regressions by Gender

\begin{tabular}{|c|c|c|c|c|c|c|c|c|}
\hline & \multicolumn{2}{|c|}{ Incorporation } & \multicolumn{2}{|c|}{ New Entrep. } & \multicolumn{2}{|c|}{ Necessity Entrep. } & \multicolumn{2}{|c|}{ Opportunity Entrep. } \\
\hline & Men & Women & Men & Women & Men & Women & Men & Women \\
\hline \multirow[t]{3}{*}{ unemprate } & -0.088 & -0.034 & -0.194 & -0.099 & -0.003 & 0.000 & -0.188 & -0.097 \\
\hline & 0.001 & 0.000 & 0.001 & 0.001 & 0.000 & 0.000 & 0.001 & 0.001 \\
\hline & {$[-145.5]^{* *}$} & {$[-6.75]^{* *}$} & {$[-169.47]^{* *}$} & {$[-124.91]^{* *}$} & {$[-9.37]^{* *}$} & {$[-1.65]+$} & {$[-173.11]^{* *}$} & {$[-128.67]^{* *}$} \\
\hline $\mathrm{N}$ & $15,243,859$ & $15,771,537$ & $13,025,277$ & $14,729,567$ & $12,919,568$ & $14,661,403$ & $13,013,383$ & $14,723,368$ \\
\hline \multirow[t]{3}{*}{ unemprate [controls] } & -0.011 & -0.003 & -0.040 & -0.019 & 0.000 & -0.001 & -0.039 & -0.017 \\
\hline & 0.001 & 0.000 & 0.002 & 0.001 & 0.001 & 0.000 & 0.001 & 0.001 \\
\hline & {$[-13.35]^{* *}$} & {$[-6.75]^{* *}$} & {$[-25.3]^{* *}$} & {$[-17.06]^{* *}$} & {$[.28]$} & {$[-2.45]^{*}$} & {$[-25.95]^{* *}$} & {$[-16.68]^{* *}$} \\
\hline $\mathrm{N}$ & $15,243,859$ & $15,771,537$ & $13,025,277$ & $14,729,567$ & $12,919,568$ & $14,661,403$ & $13,013,383$ & $14,723,368$ \\
\hline \multirow[t]{2}{*}{ unemprate_local } & -0.031 & -0.013 & -0.073 & -0.038 & 0.000 & 0.000 & -0.072 & -0.038 \\
\hline & 0.000 & 0.000 & 0.001 & 0.000 & 0.000 & 0.000 & 0.001 & 0.000 \\
\hline $\mathrm{N}$ & $15,243,859$ & $15,771,537$ & $13,025,277$ & $14,729,567$ & $12,919,568$ & $14,661,403$ & $13,013,383$ & $14,723,368$ \\
\hline \multirow[t]{3}{*}{$\begin{array}{l}\text { unemprate_local } \\
\text { [controls] }\end{array}$} & -0.004 & -0.001 & -0.019 & -0.009 & 0.000 & -0.001 & -0.019 & -0.009 \\
\hline & 0.001 & 0.000 & 0.001 & 0.001 & 0.000 & 0.000 & 0.001 & 0.001 \\
\hline & {$[-6.5]^{* *}$} & {$[-2.4]^{*}$} & {$[-17.58]^{* *}$} & {$[-12.36]^{* *}$} & {$[1.2]$} & {$[-2.59]^{*}$} & {$[-18.32]^{* *}$} & {$[-11.82]^{* *}$} \\
\hline $\mathrm{N}$ & $15,243,859$ & $15,771,537$ & $13,025,277$ & $14,729,567$ & $12,919,568$ & $14,661,403$ & $13,013,383$ & $14,723,368$ \\
\hline
\end{tabular}

Note: Four different outcomes are shown: being a new incorporated entrepreneur, being a new entrepreneur, being a new necessity entrepreneur, and being an opportunity entrepreneur. Regressions are run both with and without controls as indicated from the "[controls]" or its absence, and either the local or national unemployment rate is employed. Right hand side binary variables include: marital status, education, and province. Right hand side continuous variables- in addition to unemployment rate- are age and its square, and a quadratic for time period. Regression standard errors are clustered on the person-id. Coefficients shown with standard errors in italics underneath and t-statistics in brackets. $* *$ indicates significance at the $1 \%$ level, $*$ indicates significance at the $5 \%$ level, and + indicates significance at the $10 \%$ level.

\section{References:}

Acemoglou, D. 2001. “Good Jobs Versus Bad Jobs.” Journal of Labor Economics, 19: 1-22.

Becker, E. 1984. "Self-Employed Workers: An Update to 1983." Monthly Labor Review, 107 (7): 18 .

Bouderbat, B., Lemieux, T., and C. Riddell. 2010. "The Evolution of the Returns to Human Capital in Canada, 1980-2005." Canadian Labour Market and Skills Researcher Network Working Paper No. 55. 
Calderon, G., Iacovone, L., and L. Juarez. 2017. “Opportunity versus Necessity: Understanding the Heterogeneity of Female Micro-Entrepreneurs." World Bank Economic Review 30(Suppl. 1): S86-S96.

Caliendo, M., and A.S. Kritikos. 2009. "I Want to, But I also Need to": Start-Ups Resulting from Opportunity and Necessity." IZA Discussion Paper 4661

Card, D., Lemieux, T., and W.C. Riddell. 2003. "Unionization and Wage Inequality: A Comparative Study of the U.S., the U.K., and Canada." NBER Paper No. 9473.

Card, D., and W.C. Riddell. 1995. "Unemployment in Canada and the United States: A Further Analysis." Princeton University Industrial Relations Section Working Paper No. 352.

Congregado, E., Golpe, A.A., and S.C. Parker. 2012. "The Dynamics of Entrepreneurship: Hysteresis, Business Cycles and Government Policy.” Empirical Economics 43: 1239-1261

Dawson, C., and A. Henley. 2012. “'Push' Versus 'Pull' Entrepreneurship: An Ambiguous Distinction?" International Journal of Entrepreneurial Behaviour \& Research 18(6): 69771.

Deans, G.K., and F. Kroeger. 2004. Stretch! How Great Companies Grow in Good Times and Bad. Wiley: Hoboken, NJ, 219 pp.

Ensign, P.C., and N.P. Robinson. 2016. "Offensive and Defensive Corporate Entrepreneurship: Learning to Think Like and Outsider.” Journal of Enterprising Culture 24(2), 169-191.

Ensign, P.C., and N.P. Robinson. 2011. "Entrepreneurs because they are Immigrants or Immigrants because they are Entrepreneurs?: A Critical Examination of the Relationship between the Newcomers and the Establishment." The Journal of Entrepreneurship 21(1), $33-53$.

Fairlie, R.W., and F.M. Fossen. 2018. "Opportunity versus Necessity Entrepreneurship: Two Components of Business Creation.” IZA DP No. 11258

Farber, H.S. 1999. "Alternative and Part-time Employment Arrangements as a Response to Job Loss." Journal of Labor Economics 17(4), Part 2: S142-S169

Giacomin, O., Janssen, F., Guyot, J., and O. Lohest. 2011. "Opportunity and/or necessity entrepreneurship? The impact of the socio-economic characteristics of entrepreneurs." MPRA Paper No. 29506.

Green, D., Liu, H., Ostrovsky, Y., and G. Picot. 2016. "Immigration, Business Ownership and Employment in Canada." Analytical Studies Branch Research Paper Series, 11F0019M No. 375.

Green, D.A., and B. Sand. 2013. "Has the Canadian Labour Market Polarized?” Working Paper.

Hughes, K.D. 2003. "How are Women Faring in the Entrepreneurial Economy?" Presentation to 'Breakfast on the Hill', Canadian Federation for Humanities and Social Sciences (CFHSS).

Koellinger, P.D., and A.R. Thurik. 2012. "Entrepreneurship and the Business Cycle." Review of Economics and Statistics 94(4): 1143-1156 
Kumbhakar, S.C., and M.G. Tsionas. 2016. "An Empirical Model of Behavioral Heterogeneity." Review of Economic Analysis 8(2): 125-134.

Lin, Z., Picot, G., and J. Compton. 2000. "The Entry and Exit Dynamics of Self-Employment in Canada." Small Business Economics 15: 105-125.

Moore, C.S., and R.E. Mueller. 2002. "The transition from paid to self-employment in Canada: the importance of push factors." Applied Economics 34(6): 791-801.

Ostrovsky, Y., and G. Picot. 2018. "The Exit and Survival Patterns of Immigrant Entrepreneurs: The Case of Private Incorporated Companies." Analytical Studies Branch Research Paper Series, 11F0019M No. 401.

Ostrovsky, Y., Picot, G, and D. Leung. 2019. "The financing of immigrant-owned firms in Canada." Small Business Economics S2: 303-317.

Parker, S.C., Congregado, E., and A.A. Golpe. 2012. "Is Entrepreneurship a Leading or Lagged Indicator of the Business Cycle? Evidence from UK Self-employment Data." International Small Business Journal 30(7): 736-753

Piasna, A. 2017. 'Bad jobs' recovery? European Job Quality Index 2005-2015. ETUI Working Paper 2017.06.

Riddell, W.C. 2009. "Economic Change and Worker Displacement in Canada: Consequences and Policy Responses." Canadian Labour Market and Skills Researcher Network Working Paper No. 33.

Robichaud, Y., LeBrasseur, R., and K.V. Nagarajan. 2010. "Necessity and Opportunity-driven Entrepreneurs in Canada: An Investigation into their Characteristics and an Appraisal of the Role of Gender." Journal of Applied Business and Economics 11: 59-79

Schuetze, H.J. 2000. "Taxes, economic conditions and recent trends in male self-employment: a Canada-US comparison.” Labour Economics 7: 507-544.

Tal, B. 2019. "Canada's Income Problem." In Focus 1-4. https://economics.cibccm.com/economicsweb/cds?ID=8359\&TYPE=EC PDF 